\title{
Електромагнітні завади на залізничному транспорті: теоретичні засади та класифікація
}

Для зменшення кількості збоїв у роботі обладнання систем залізничної автоматики, а тим самим $i$ зменшення порушень графіка руху поӥздів, щцо завжди призводить до фінансових втрат, доцільно використовувати методологію оптимального приймання сигналів. Проаналізовано причини збоїв у роботі системи автоматичної локомотивної сигналізації, поданої у вигляді трьох функціональних блоків передавальних колійних пристроїв, лінї зв'язку та приймальних локомотивних пристроїв. Метою роботи $\epsilon$ аналіз та класифікація електромагнітних завад, щуо можуть мати негативний вплив на функціонування залізничної автоматики. Зниження інтенсивності збоїв у роботі автоматичної локомотивної сигналізації призведе до збільшення рівня безпеки та безперебійності руху поӥздів.

Ключові слова: рейкове коло, автоматична локомотивна сигналізачія, завадостійкість, електромагнітні завади, стійкість роботи, збої.

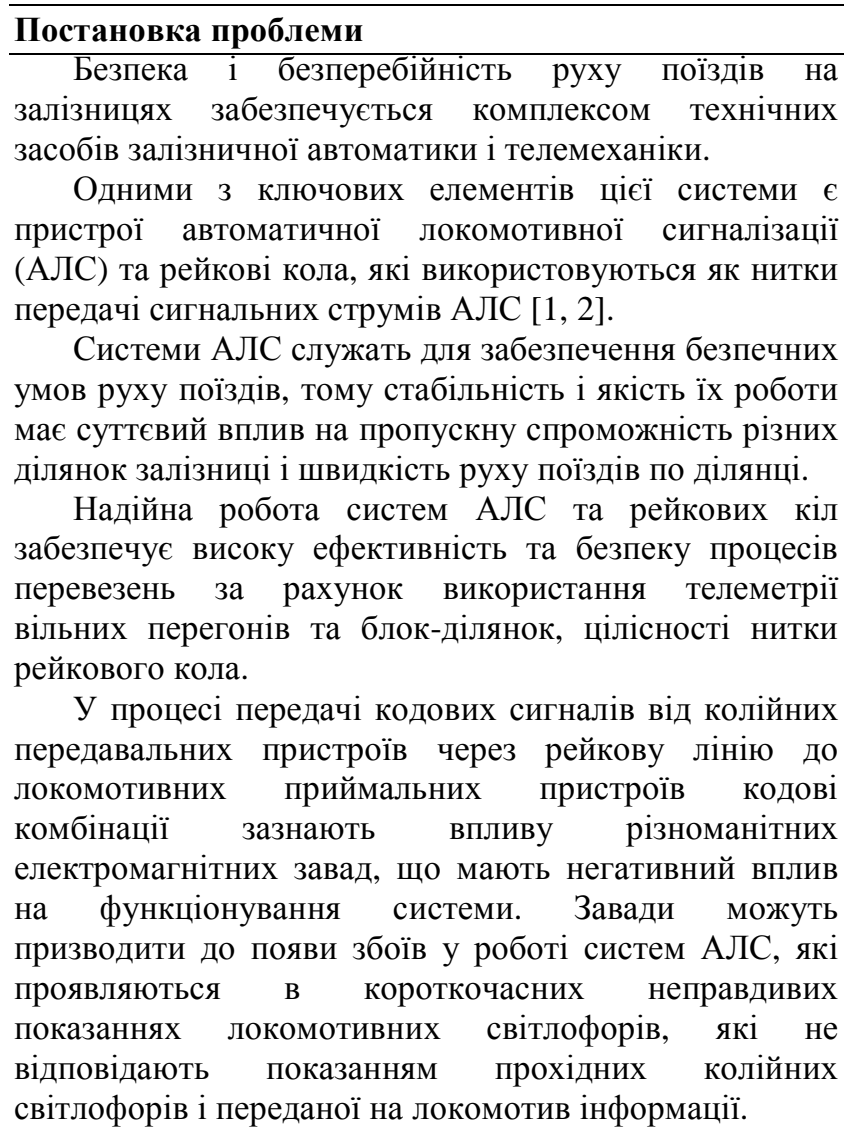

(ㄱ Л. П. Єрмоленко, 2019

\section{Аналіз останніх досліджень і публікацій}

У наш час більшість ділянок залізниць обладнані системою автоматичної локомотивної сигналізації, у якій колійні передавальні пристрої виробляють кодові посилки змінного струму з частотою кодування 25, 50 або 75 Гц, що обирається залежно від виду тяги поїздів та роду тягового струму [11].

У реальних умовах практично завжди наявні завади, що призводять до спотворення кодових посилок.

Джерелами їх виникнення можуть бути системи тягового електроживлення, рухомий склад, прилади АЛС, інші рейкові кола, повітряні лінії електричних мереж і наземна інфраструктура, грозові розряди та ін.

Найбільший заважаючий вплив надають завади, спричинені негативним впливом зворотного тягового струму і силового обладнання локомотивів, а також нерівномірною залишковою намагніченістю рейок, як ходових, так і покладених у колії і по краях шпал і на узбіччі [6-9].

Якщо вони перебувають у допустимих межах, то нормальна передача не порушується. Якщо ж завади перевищують допустимі рівні завадостійкості, передача та приймання кодових посилок стають нестійкими.

Виділення не вирішених раніше частин загальної
проблеми
Аналіз видів і параметрів завад, що діють у каналі
зв'язку системи АЛС [3], дає неповне уявлення про
цей вплив. Для оцінки величини внеску кожної завади
в напругу на затискачах локомотивних котушок
розглянуто часові та частотні характеристики цих
завад. Математична модель суміші сигналу та
багатокомпонентної завади на вході колійних
пристроїв залізничної автоматики [2] розглядається з IКC3Т, 2019 №3 
точки зору забезпечення максимальної завадостійкості для побудови приймача сигналів автоматичної локомотивної сигналізації неперервного типу (АЛСН), що адаптується до завадової обстановки шляхом неперервної корекції всього алгоритму обробки характеристик суміші сигналу та завади. Але ж у наш час пріоритетами розвитку залізничного транспорту України є спроможність істотно підвищити швидкість руху поїздів. Тому доцільно було б розглянути більш досконалу систему автоматичної локомотивної сигналізації єдиного ряду 3 неперервним каналом зв'язку.

\section{Формулювання цілей}

Метою роботи $\epsilon$ аналіз та класифікація електромагнітних завад, що можуть мати негативний вплив на функціонування систем залізничної автоматики.

\section{Основний матеріал}

Пристрої систем АЛС працюють у дуже важких експлуатаційних та кліматичних умовах під підвищеними електричними, механічними та температурними навантаженнями. Не слід виключати вплив людини [11]. Важливою умовою при проведенні аналізу причин збоїв у роботі систем АЛС $є$ те, що відмова відбувається у конкретній поїзній ситуації, при визначеній електромагнітній обстановці та при заданому стані колійних і локомотивних пристроїв. Усі фактори змінюються випадково.

Систему АЛС можна подати у вигляді трьох функціональних блоків - передавальних колійних пристроїв, лінії зв'язку та приймальних локомотивних пристроїв. У кожному з цих блоків можуть виникати внутрішні причини збоїв чи міститися пристрої, на які можуть впливати зовнішні негативні фактори, що призводять до порушень роботи всієї системи АЛС.

На рис. 1 наведено основні негативні фактори, що впливають на стійкість роботи систем АЛС та призводять до невиконання заданого обсягу перевезень через порушення умов безпеки та безперебійності руху поїздів.

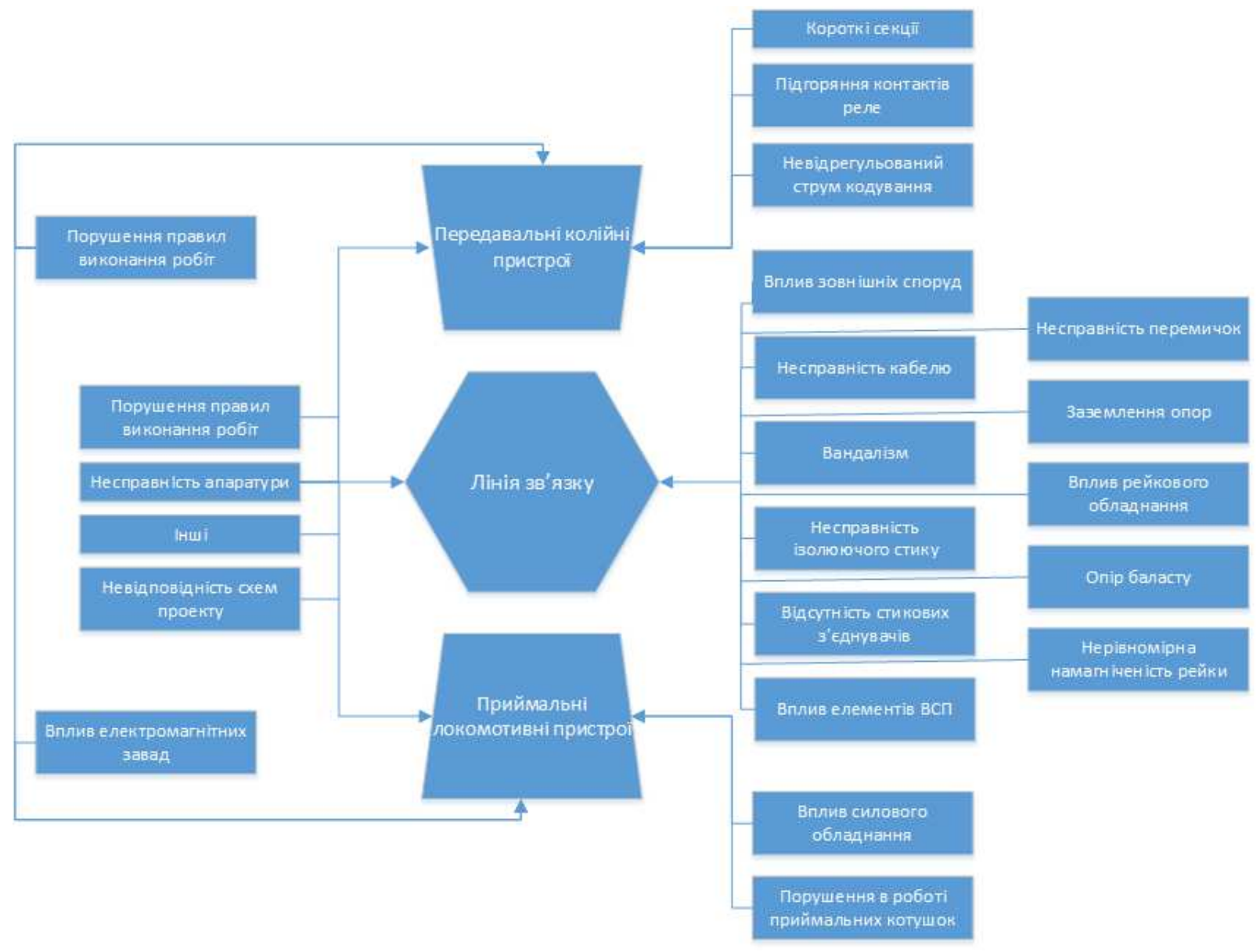

Рис. 1. Основні негативні фактори, що впливають на роботу систем АЛС 
За результатами аналізу значної кількості відмов за декілька років та їх причин на електрифікованих ділянках залізниць установлено, що найбільш схильні до негативного впливу заважаючих факторів $\epsilon$ пристрої лінії зв'язку між передавальною та приймальною апаратурою [11]. Рейкова лінія належить до колійних пристроїв і тому схильна до впливу практично всіх видів завад, що відображається в більш ніж $70 \%$ збоїв. Тому підвищення завадостійкості пристроїв АЛС просто необхідне в наш час для задоволення потреб сучасного суспільства в перевезеннях.
Складність виявлення причин збоїв у роботі систем АЛСН визначається тим, що збій може виникнути від дії одного чи декількох несприятливих факторів у випадковому сполученні при різному рівні впливу.

За даними статистики відмов, за останні чотири роки найбільша кількість короткочасних порушень роботи автоматичної локомотивної сигналізації припадає на несправність приладів кодування та спотворення часових параметрів коду (рис. 2) [13].

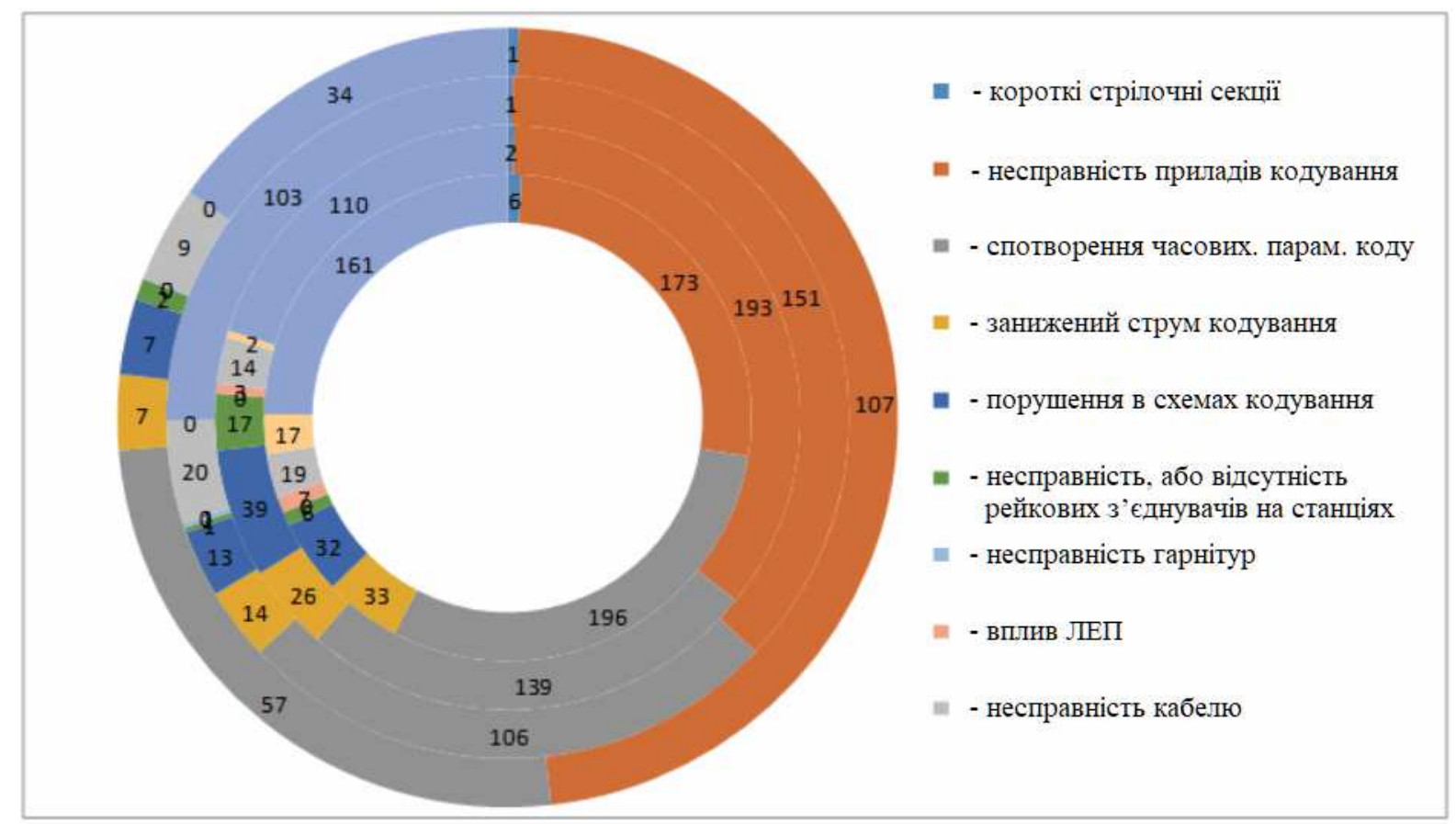

Рис. 2. Статистика збоїв у роботі АЛС

Передавальні колійні пристрої та рейкова лінія належать до колійних пристроїв $\mathrm{i}$ тому схильні до впливу практично всіх видів завад. Рейкові кола використовуються як нитки передачі сигнальних струмів систем автоблокування (АБ) та АЛС i зворотного тягового струму [3].

Традиційно електромагнітні завади, що впливають на рейкові кола, розділяють на імпульсні, синусоїдальні та флуктуаційні [14]. Імпульсні завади це завади, що зосереджені у часі. Вони виникають через порушення контакту між полозом струмоприймача та контактною лінією, аварійні процеси у тяговій мережі або грозові розряди.

До синусоїдальних або зосереджених за спектром частот завад належать сигнали АЛС, гармонічні складові тягового струму та сигнали сусідніх рейкових кіл.
До флуктуаційних або гладких завад можна віднести завади, що виникають безпосередньо у рейкових колах та пов'язані зі змінами у роботі його елементів. Крім того, до флуктуаційних завад можна віднести електромагнітні шуми зовнішнього середовища.

Ця класифікація, на наш погляд, є недостатньо деталізованою та не в повному обсязі відповідає вимогам електромагнітної сумісності приладів та сучасних методів урахування завад і захисту рейкових кіл.

На наш погляд, електромагнітні завади слід розглядати відповідно до електромагнітної обстановки, у якій технічні засоби повинні функціонувати без порушень. Таким чином, електромагнітні завади можна поділити на три категорії, що характеризують електромагнітну обстановку: 
- низькочастотні електромагнітні завади;

- високочастотні електромагнітні завади;

- електростатичні розряди.

Такий поділ відповідає вимогам ідентифікації електромагнітних завад у конкретній електромагнітній обстановці. Більшість стандартів до низькочастотних завад відносить завади, переважна частина спектра яких перебуває нижче 9 кГц, а до високочастотних завади, спектр яких перебуває значно вище 9 кГц.

Низькочастотні та високочастотні електромагнітні завади також слід поділяти на кондуктивні та випромінювані.

Таким чином, класифікація електромагнітних завад може мати вигляд, поданий у таблиці $[3,10]$.

Класифікація електромагнітних завад

\begin{tabular}{|c|c|}
\hline Назва завади & Вид завади \\
\hline $\begin{array}{l}\text { Кондуктивні } \\
\text { низькочастотні } \\
\text { електромагнітні завади }\end{array}$ & $\begin{array}{l}\text { Гармоніки та інтергармоніки напруги електроживлення } \\
\text { Напруга сигналів, що передаються в системах електроживлення } \\
\text { Коливання напруги електроживлення } \\
\text { Короткострокові переривання, провали або викиди напруги електроживлення } \\
\text { Відхилення напруги електроживлення } \\
\text { Асиметрія напруги в системах електроживлення } \\
\text { Зміна частоти живильної напруги } \\
\text { Наведені низькочастотні напруги }\end{array}$ \\
\hline $\begin{array}{l}\text { Випромінювані } \\
\text { низькочастотні } \\
\text { електромагнітні завади: }\end{array}$ & $\begin{array}{l}\text { Магнітні поля } \\
\text { Електричні поля }\end{array}$ \\
\hline $\begin{array}{l}\text { Кондуктивні } \\
\text { високочастотні } \\
\text { електромагнітні завади }\end{array}$ & $\begin{array}{l}\text { Наведені напруги та струми безперервних коливань } \\
\text { Аперіодичні і коливальні перехідні процеси }\end{array}$ \\
\hline $\begin{array}{l}\text { Випромінювані } \\
\text { високочастотні завади: }\end{array}$ & $\begin{array}{l}\text { Магнітні поля } \\
\text { Електричні поля } \\
\text { Електромагнітні поля, що виникають через безперервні коливання або перехідні } \\
\text { процеси }\end{array}$ \\
\hline Електростатичні розряди & \\
\hline
\end{tabular}

Гармоніки - це синусоїдальні зміни напруги в системі електроживлення, що мають частоту, кратну частоті мережі. Гармоніки є результатом протікання струмів, що виникають при нелінійних навантаженнях. Вказані струми спричиняють падіння напруги при повному опорі в мережі.

Електромагнітні завади в частині сигналів, що передаються в системах електроживлення, залежать від діапазону частот, у якому перебуває система управління, та від напряму застосування електричної мережі.

У системах електроживлення можуть відбуватися коливання напруги різноманітної природи, зокрема безперервні або такі коливання, що випадково повторюються в межах установлених допустимих відхилень електричної мережі; відхилення напруги, що являє собою повільну зміну напруги через плавні зміни навантаження в електричній мережі; провали напруги або короткострокові перерви у живленні терміном до декількох секунд; несиметрія напруги, що виникає при нерівності фазних напруг або зміні нормального фазного співвідношення. Провали живлення, що тривають більше однієї хвилини слід, вважати не низькочастотними електромагнітними завадами, а вимкненням джерела електроживлення.

Незважаючи на те, що частота в системах електропостачання зазвичай достатньо стабільна, іiі зміни можуть досягати значень у 4 \% від номінального значення частоти; значні зміни частоти можуть бути спричинені аваріями або реконфігурацією системи електроживлення.

Низькочастотні струми, що протікають у силових кабелях, можуть залежно від сили струму, умов розміщення i типу кабелів наводити низькочастотні електромагнітні завади в сигнальних кабелях, кабелях управління, що підключені до систем телекерування та автоблокування на ділянках залізничного руху.

Низькочастотні магнітні поля генеруються різноманітними джерелами, а саме: лініями електропостачання, що розташовані у безпосередній близькості до рейкових кіл, особливо повітряними, трансформаторами та іншим обладнанням систем електропостачання. 
Повітряні лінії електропередач високої напруги генерують електричні поля високої напруги, які $\epsilon$ джерелом розповсюдження електромагнітних завад.

Кондуктивні високочастотні електромагнітні завади виникають в електричних з'єднаннях технічних засобів або лініях електроживлення чи сигнальних i управлінських електричних лініях. Кондуктивні високочастотні електромагнітні завади можуть бути поділені на два основних види: безперервні завади, або наведені безперервні коливання та аперіодичні i коливальні перехідні процеси. Безперервні завади характеризуються амплітудою, частотою і видом модуляції наведеної напруги, а також внутрішнім опором джерела завад; аперіодичні коливальні процеси - швидкістю наростання, тривалістю, піковим значенням, спектром, частотою коливання, частотою виникнення.

Для цілей класифікації кондуктивні високочастотні перехідні електромагнітні завади поділяють на дві групи: аперіодичні і коливальні. Серед них можна виділити імпульсні завади великої потужності, які здебільшого виникають через розряди блискавок або спрацювання плавких запобіжників. Надкороткі імпульсні завади асоціюються із завадами “іскріння" при перемиканні навантажень в електричних мережах. Коливальні перехідні завади мають частоту коливань від 1 кГц (переважно у результаті перемикання конденсаторів) до декількох мілігерців (при роз'єднанні мереж або при комутаціях).

До електромагнітних завад, що формуються коливальним електромагнітним полем, належать такі, у яких щонайменше $90 \%$ середньої потужності перебуває в спектральному інтервалі $\left[f_{\min }, f_{\max }\right]$, який можна визначити як $\frac{f_{\max }}{f_{\min }} \leq 1,2$.

Випромінювані імпульсні

(перехідні електромагнітні) завади являють собою завади, що, незважаючи на малу тривалість можуть мати суттєвий вплив на функціонування рейкових кіл та систем автоматичної локомотивної сигналізації через значну швидкість нарощування імпульсу. До імпульсних перехідних електромагнітних завад відносять електромагнітні поля, тривалість яких не перевищує 200 мс та зміна полярності яких протягом збурення не перевищує більше ніж 10 разів.

Електростатичні розряди виникають у результаті наближення зарядженого об'єкта до іншого об'єкта (технічного засобу залізничної автоматики). Рецептор електростатичного розряду спочатку зазнає впливу електричного поля, а потім після пробоїв діелектрика виникає розряд із перехідним струмом складної природи. Рівень електромагнітних завад при цьому суттєво залежить від провідності поверхонь та вологості повітря.

\section{Висновки}

Зважаючи на те, що рейкові кола, системи автоблокування та системи автоматичної локомотивної сигналізації є одними 3 найважливіших елементів, що забезпечують безпеку та надійність руху залізничного транспорту, вони потребують значної уваги, особливо в галузі захисту від електромагнітних завад. Запропонований у роботі підхід до класифікації електромагнітних завад та визначені негативні фактори впливу на роботу АЛС дають змогу конкретизувати електромагнітні завади, що мають критичний вплив на роботу засобів залізничної автоматики, та сконцентрувати зусилля на розробці й подальшому удосконаленні методів захисту від них систем залізничного транспорту.

\section{Список використаних джерел}

1. Правила безпеки руху на залізничному транспорті України. Посібник для вивчення "Правил технічної експлуатації залізниць Украӥни”, “Інструкиії 3 сигналізації” та "Інструкиії з руху поїзів $i$ маневрової роботи”. Харків, 2002. 350 с.

2. Кулик П. Д., Ивакин Н. С., Удовиков А. А. Тональные рельсовые цепи в системах ЖАТ: построение, регулировка, обслуживание, поиск и устранение неисправностей, повышение эксплуатационной надежности. Киев: Издательский дом «Мануфактура», 2004. 288 с.

3. Ананьева О. М., Давиденко М. Г., Бабаев М. М. Виды и параметры помех, действующих в канале связи системы автоматической локомотивной сигнализации. Збірник наукових праць Украӥнського державного університету залізничного транспорту. Харків: УкрДУЗТ, 2016. Вип. 163. С. 20-25.

4. Ананьева О. М. Математическая модель смеси сигнала и многокомпонентной помехи на входе путевых устройств железнодорожной автоматики. Інформаційно-керуючі системи на залізничному транспорті. 2017. № 6. С. 16-19.

5. Ananieva O., Babaiev M., Blyndiuk V., Davidenko M. Design of a device for optimal reception of signals against the background of a two-component Markov interference. Eastern-European Journal of Enterprise Technologies. 2017. № 6, Issue 9 (90). P. 4-9. DOI: 10.15587/1729-4061.2017.118869.

6. Пультяков А. В., Трофимов Ю. А. Анализ влияния неравномерной намагниченности рельсов на устойчивость работы АЛСН. Современные технологии. Системный анализ. Моделирование. 2011. № 1 (30). С. 206-210.

7. Трофимов Ю. А., Пультяков А. В. Устойчивость работы локомотивных устройств АЛС на участках с электротягой переменного тока. Материаль межвуз. науч.-практ. конф. Иркутск: ИрГУПС, 2011. C. 207-211. 
8. Шаманов В. И., Пультяков А. В., Трофимов Ю. А. Влияние условий эксплуатации на устойчивость работы АЛСН. Железнодорожный транспорт. 2009. № 5. C.46-50.

9. Шаманов В. И. Электромагнитная совместимость систем железнодорожной автоматики и телемеханики: учеб. пособие. Москва: УМЦ по образованию на ж.-д. транспорте, 2013. 244 с.

10. Панченко С. В., Ананьєва О. М., Давиденко М. Г., Бабаєв М. М. Взаємна кореляція компонентів завад роботі тональних рейкових кіл. Інформаційно-керуючі системи на залізничному транспорті. 2018. № 3. C. 3-7.

11. Pul'tyakov A. V., Skorobogatov M. E. System analysis of sustainability of automatic locomotive signaling systems. Modern technologies. System analysis. Modeling. 2018. Vol. 57. No. 1. P. 79-89. DOI: 10.26731 / 1813-9108.2018.1 (57). 79-89.

12. Ananieva O., Babaiev M., Blyndiuk V., Davidenko M. Development of a device for the optimal reception of signals against the background of an additive threecomponent interference. Eastern-European Journal of Enterprise Technologies. 2019. № 2. Issue 2/9 (98). P. 6-13. DOI: 10.15587/1729-4061.2019.159310.

13. Офіційний сайт Державної служби статистики України. URL: www.ukrstat.gov.ua (назва з екрана).

14. Єрмоленко Л. П. Класифікація електромагнітних завад на залізничному транспорті. Прикладні науково-технічні дослідження: матеріали II міжнар. наук.-практ. конф., 3-5 квіт. 2018. Академія технічних наук України. - ІваноФранківськ: Симфонія форте, 2018. 191 с.

Ермоленко Л. П. Электромагнитные помехи на железнодорожном транспорте: теоретические основы и классификация.

Аннотация. Для уменьшения количества сбоев в работе оборудования железнодорожной автоматики, а тем самым и уменьшения нарушений графика движения поездов, который всегда приводит к финансовым потерям, целесообразно использовать методологию оптимального приема сигналов. Проведен анализ причин сбоев в работе системы автоматической локомотивной сигнализации, представленной в виде трех функциональных блоков передающих путевых устройств, линии связи и приемных локомотивных устройств. Целью работы является анализ и классификация электромагнитных помех, которые могут оказывать отрицательное влияние на функционирование систем железнодорожной автоматики. Снижение интенсивности сбоев в работе автоматической локомотивной сигнализации приведет к увеличению уровня безопасности и бесперебойности движения поездов.

Ключевые слова: рельсовая цепь, автоматическая локомотивная сигнализация, помехоустойчивость, электромагнитные помехи, устойчивость работы, сбой.
Yermolenko L. Electromagnetic interference on the railway transport: theoretical foundations and classification.

Abstract. In order to reduce the amount of failures in the operations of the equipment of the railway automation systems, and thereby reduce the violations of the train schedule, which always leads to financial losses, it is better to use the methodology of optimal signal reception. The analysis of causes of failures in the work of the systems of railway automation, presented as system of three functional units transmission tracks, communication lines and locomotive receivers are carried out.

Internal causes of failure may occur and devices with a negative impact may present in each block, which leads to disturbances in the operation of the entire system of automatic locomotive signaling. It has been shown that the practical implementation and application of the developed devices for increasing the electromagnetic compatibility of automatic locomotive signaling with the reverse traction network should provide for the suppression of powerful interference from reverse traction currents occurring on locomotive receiving coils in heavy traffic trains.It should also ensure suppression of interference from the uneven magnetic field of the rails laid in the path or in the track and at the ends of the sleepers.

The purpose of the work is analysis and classification of electromagnetic interference that may have a negative effect on the functioning of the railway automation systems. Lowering the intensity of crashes in the operation of automatic locomotive signaling increase the level of safety and continuity of trains.

Bearing in mind that track circuits, auto-lock systems and automatic locomotive signaling systems are among the most important elements for ensuring the safety and reliability of railway transport, they require considerable attention, especially in the field of electromagnetic interference protection. The proposed approach to the classification of electromagnetic interference and the identified negative factors of influence on the work of ALS allow to specify the electromagnetic interference that has a critical impact on the work of the of railway automation equipment and to concentrate efforts on the development and further improvement of the methods of protection against them on railway transport systems.

Key words: track circuit, automatic locomotive signaling, immunity, electromagnetic interference, stability of work, failures.

Надійшла 29.05.2019 p.

Срмоленко Людмила Павлівна, аспірантка, кафедра автоматики та комп'ютерного телекерування рухом поїздів Українського державного університету залізничного транспорту, м. Харків, Україна. E-mail: ermolenkolp1@gmail.com ORCID: http://org/0000-0003$\underline{0732-3999}$

Yermolenko Liudmyla, Postgraduate student, Department of Automation and computer remote control of train operation Ukrainian State University of Railway Transport, Kharkiv, Ukraine. E-mail: ermolenkolpl@gmail.com ORCID: http://org/0000-0003-0732-3999 